\section{NCF1-339 polymorphism and systemic lupus erythematosus}

We read the publication on 'NCF1-339 polymorphism is associated with altered formation of neutrophil extracellular traps, high serum interferon activity and antiphospholipid syndrome (APS) in systemic lupus erythematosus (SLE)' with great interest. ${ }^{1}$ Linge et al concluded that "we revealed a striking connection between the ROS deficient NCF1-339 genotypes and the presence of phospholipid antibodies and APS". "The NCF1-339 rs201802880 polymorphism is a single mutation that might cause the molecular change. Due to the mutation, the molecular weight change and the alteration of the phenotypic expression is the result. In the present report, Linge et al studied on only one genetic polymorphism and did not assess the possible effects of other genetic polymorphisms that might have clinical association with SLE. The examples of those genetic polymorphisms are paraoxonase-1 gene and PAL-1 polymorphisms. ${ }^{23}$ Further studies to access the possible confounding factors of other genetic polymorphisms are required.

\section{Beuy Joob $®$, Viroj Wiwanitkit}

Sanitation1 Medical Academic Center, Bangkok, Thailand

Correspondence to Dr Beuy Joob, Sanitation1 Medical Academic Center, Bangkok 10140, Thailand; beuyjoob@hotmail.com

Contributors Both authors have equal contributions (BJ $50 \%$, VW 50 \%).
Competing interests None declared.

Patient consent for publication Not required.

Provenance and peer review Not commissioned; internally peer reviewed.

(c) Author(s) (or their employer(s)) 2019. No commercial re-use. See rights and permissions. Published by BMJ.

\section{A) Check for updates}

To cite Joob B, Wiwanitkit V. Ann Rheum Dis Epub ahead of print: [please include Day Month Year]. doi:10.1136/annrheumdis-2019-216629

Received 11 November 2019

Accepted 17 November 2019

Ann Rheum Dis 2019:0:1. doi:10.1136/annrheumdis-2019-216629

ORCID iD

Beuy Joob http://orcid.org/0000-0002-5281-0369

\section{REFERENCES}

1 Linge P, Arve S, Olsson LM, et al. NCF1-339 polymorphism is associated with altered formation of neutrophil extracellular traps, high serum interferon activity and antiphospholipid syndrome in systemic lupus erythematosus. Ann Rheum Dis 2019. doi:10.1136/annrheumdis-2019-215820. [Epub ahead of print: 8 Nov 2019].

2 Ibrahim AA, El-Lebedy D, Ashmawy I, et al. Association between paraoxonase-1 gene Q192R and L55M polymorphisms in systemic lupus erythematosus (SLE) and anti-phospholipid syndrome (APS) in a population from Cairo of Egypt. Clin Rheumatol 2017:36:1305-10

3 Savov A, Andonova S, Tanev D, et al. [PAL-1 5G/4G polymorphism in patients with systemic lupus erythematosus]. Akush Ginekol 2014;53:13-17. 